\title{
ANL/ER/CP-93863 CONF-980/24--
}

\section{AIRCRAFT MEASUREMENTS OF NITROGEN DIOXIDE AND \\ PEROXYACYL NITRATES USING LUMINOL CHEMILUMINESCENCE WITH FAST CAPILLARY GAS CHROMATOGRAPHY}

Jeffrey S. Gaffney* and Nancy A. Marley

Environmental Research Division

Argonne National Laboratory, Argonne, Illinois, 60439

and

Paul J. Drayton

Department of Geophysical Sciences

University of Chicago, Chicago, IL, 60637
RECEIVED

OCT 241997

OSTI

Extended abstract of oral presentation (Paper J3.11) to be presented at the 78th American Meteorological Society Annual Meeting, Phoenix, Arizona, January 11-16, 1998.

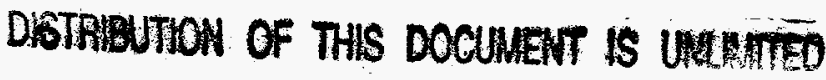

September 1997

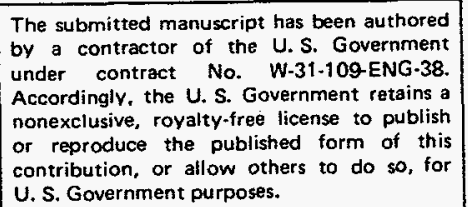

This research was carried out at Argonne National Laboratory for the U.S. Department of Energy under contract No. W-31-109-ENG-38 as part of the Office of Biological and Environmental Research Atmospheric Chemistry Program. 


\section{DISCLAIMER}

This report was prepared as an account of work sponsored by an agency of the United States Government. Neither the United States Government nor any agency thereof, nor any of their employees, makes any warranty, express or implied, or assumes any legal liability or responsibility for the accuracy, completeness, or usefulness of any information, apparatus, product, or process disclosed, or represents that its use would not infringe privately owned rights. Reference herein to any specific commercial product, process, or service by trade name, trademark, manufacturer, or otherwise does not necessarily constitute or imply its endorsement, recommendation, or favoring by the United States Government or any agency thereof. The views and opinions of authors expressed herein do not necessarily state or reflect those of the United States Government or any agency thereof. 


\section{DISCLAIMER}

Portions of this document may be illegible electronic image products. Images are produced from the best available original document. 


\author{
Jeffrey S. Gaffney* and Nancy A. Marley \\ Environmental Research Division \\ Argonne National Laboratory, Argonne, Illinois
}

and

Paul J. Drayton

Department of Geophysical Sciences

University of Chicago, Chicago, IL

\section{INTRODUCTION}

Peroxyacyl nitrates (PANs) and nitrogen dioxide $\left(\mathrm{NO}_{2}\right)$ are important trace gas species associated with photochemical air pollution. Peroxyacyl nitrates are a class of organic oxidants that have the general chemical structure $\mathrm{RC}=0 \mathrm{O}-\mathrm{O}-\mathrm{NO} 2$. The most common family members of the PANs are peroxyacetyl nitrate (PAN, $\mathrm{R}=\mathrm{CH}_{3}$-), peroxypropionyl nitrate (PPN, $\mathrm{R}=\mathrm{CH}_{3} \mathrm{CH}_{2}$-), and peroxybutryl nitrate (PBN, $\mathrm{R}=\mathrm{CH}_{3} \mathrm{CH}_{2} \mathrm{CH}_{2}-$ ).

The PANs are in thermal equilibrium with the peroxyacetyl radical ( $\mathrm{RC}=\mathrm{O}-\mathrm{OO} \mathrm{O}^{\circ}$ ) and $\mathrm{NO}_{2}$ (Gaffney et al. 1989). Because PANs are trapped peroxy radicals, they are an important indicator species of the photochemical age of an air parcel, as well as being a means of long-range transporting of $\mathrm{NO}_{2}$, leading to the formation of regional ozone and other oxidants. Typically, PANs are measured by using a gas chromatograph with electron-capture detection (ECD). Once automated, this method has been shown to be reliable and quite sensitive, allowing the levels of PANs to be measured at low parts per trillion in the troposphere (e.g. Gaffney et al. 1993). Unfortunately, a number of other atmospheric gases also have strong $E C D$ signals or act as inferences (e.g., $\mathrm{O}_{2}$, freons, $\mathrm{H}_{2} \mathrm{O}$ ) and limit the speed in which the analysis can be completed. Currently, the shortest analysis time for PAN is approx. 5 minutes with ECD (e.g. Williams et al. 1997).

We recently examined the luminol detection of $\mathrm{NO}_{2}$ and PANs using gas capillary chromatography for

- Corresponding author address: Jeffrey S. Gaffney, Environmental Research Division, Argonne National Laboratory, Argonne, IL 60439; email: jeff_gaffney@qmgate.anl.gov. rapid monitoring of these important trace gases (Gaffney et al., Atmos. Environ., in press). Analysis of the PANs (PAN, PPN, and PBN) and $\mathrm{NO}_{2}$ in one minute has been demonstrated in laboratory studies by using this approach. Reported here are modifications of this instrument for aircraft operation and preliminary results from test flights taken near Pasco, Washington in August of 1997.

\section{EXPERIMENTAL}

The details of the instrumental design are given in detail in Gaffney et al., in press, but will be briefly described here. A luminol nitrogen dioxide detector (Scintrex LMA-3) has been modified to make the $\mathrm{NO}_{2}$ and PANs measurements. An air sample is pulled through an inlet tube into a six-port sampling valve which is electronically actuated (Valco timer and Cheminert valve). For these studies a $5 \mathrm{~cm}^{3}$ sampling loop was used and injected into a $3 \mathrm{~m} \mathrm{DB}-$ 1 capillary column for separation of the PANs and $\mathrm{NO}_{2}$. Retention times for $\mathrm{NO}_{2}$ and PAN at 125 $\mathrm{cm} / \mathrm{min}$ carrier gas flow $\left(5 \% \mathrm{O}_{2}\right.$ in $\left.\mathrm{He}\right)$ were 0.23 and 0.32 minutes, respectively. The recording integrator (Hewlett-Packard 3395) has been interfaced to a lap top computer (Toshiba) using Hewlett Packard Peak96 software, which allows automated collection of the data onboard the aircraft. The instrument consisted of a mounting rack, the modified-LMA-3 with capillary column operated at ambient temperature, sampling valve and associated electronics (automated timing system). carrier gas bottle and regulator, peristaltic pump for the LMA-3 (external), recording integrator, and laptop computer. Instrument weight with the rack included was approx. $190 \mathrm{lb}$.

PAN and $\mathrm{NO}_{2}$ retention times were checked using a PAN synthesized standard (Gaffney et al. 1984). 
Calibrations were performed using certified $\mathrm{NO}_{2}$ standards and standard dilution techniques. PAN was assumed to have approx. the same sensitivity for these preliminary analyses using the $5 \% \mathrm{O}_{2} / \mathrm{He}$ carrier gas (Gaffney et al. in press). Samples were taken into the sampling loop using a small air pump operated at $825 \mathrm{cc} /$ minute flow by pulling the outside air from inside a 1 inch Teflon Sampling Pipe which was inside an external sampling inlet (ram-air) on the aircraft while in flight. The $5 \mathrm{~cm}^{3}$ samples were injected for $10 \mathrm{~s}$ followed by $50 \mathrm{~s}$ for the completion of the analysis before the next analysis was initiated. $\mathrm{NO}_{2}$ and PAN analysis were completed in one minute for the flights during this testing program.

The aircraft used for these studies was the G-1 aircraft owned by the U.S. Department of Energy and operated by Pacific Northwest National Laboratory. The flight no. 3 described in this work was a flight originating at Pasco airport and conducted on August 13, 1997 from approx. 1700 to $1945 \mathrm{GMT}$. The instrument was initially started on the ground and was operated from takeoff until shortly before landing during this flight at one minute intervals.

\section{RESULTS AND DISCUSSION}

In Figures $1 \mathrm{a}, 1 \mathrm{~b}$, and 2 the results of one minute analyses are presented for the flight no. 3 taken on August 13, 1997 from Pasco airport for $\mathrm{NO}_{2}$ and PAN, respectively. As expected the initial $\mathrm{NO}_{2}$ levels were observed to be quite high at the airport and during the takeoff period and rapidly fell to background levels. The flight took us around a paper mill in the area where we were able to detect the plume from the mill at $1500 \mathrm{ft}$ altitude. The later part of the flight involved measurements at $4000 \mathrm{ft}$ and $8000 \mathrm{ft}$ altitude. At the $4000 \mathrm{ft}$ altitude a plume from a grass fire below was detected using the instrument indicating a small source of $\mathrm{NO}_{2}$ from the fire, as anticipated.

Figure 3. shows the results of PAN/NO 2 analysis for the flight. Note the increase in the $\mathrm{PAN} / \mathrm{NO}_{2}$ ratio with time follows the altitude of the flight path. This is consistent with the lower temperatures at the higher altitudes leading to thermal stabilization of the PAN. The air quality during these studies over this area was very clean. $\mathrm{NO}_{2}$ levels outside of the plumes were on the order of $100 \mathrm{ppt}$ at $1500 \mathrm{ft}$ and dropped to around $50 \mathrm{ppt}$ at $8000 \mathrm{ft}$.
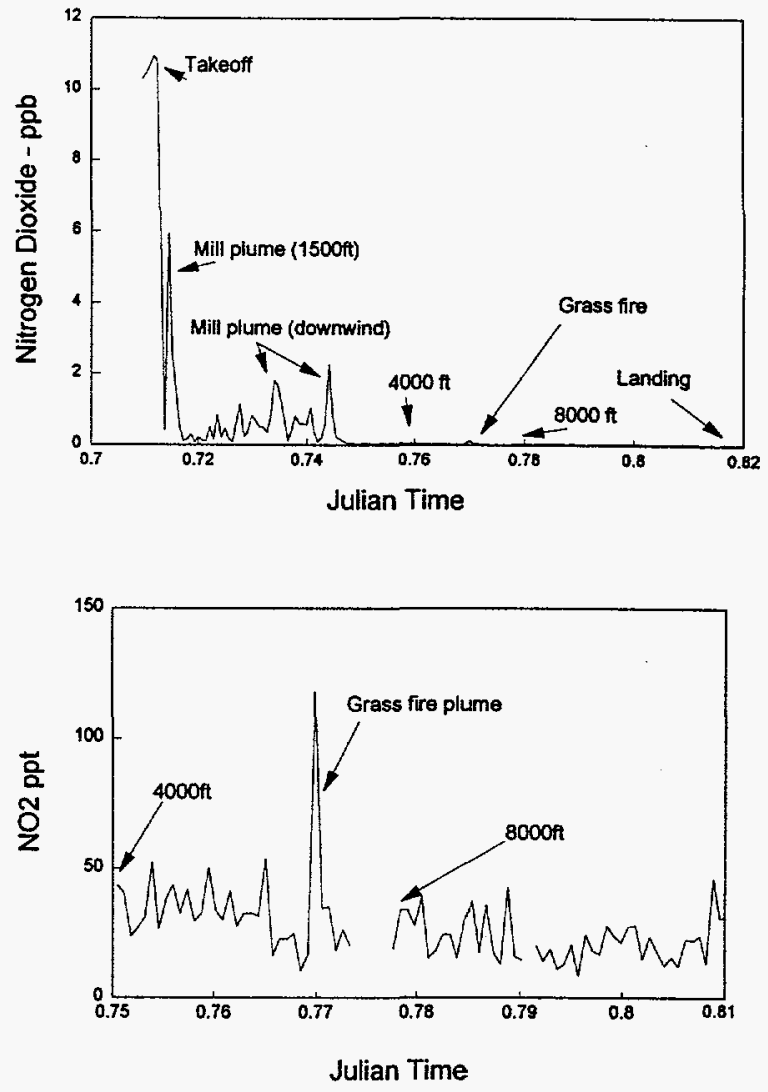

Figures 1a. (ppb) and $1 \mathrm{~b} . \mathrm{NO}_{2}$ (ppt) levels observed during flight no. 3 from Pasco, WA on 8/13/97. Figure $1 \mathrm{~b}$. shows the levels at $4000 \mathrm{ft}$ and $8000 \mathrm{ft}$. and indicates detection of $\mathrm{NO}_{2}$ source from grass fire below.

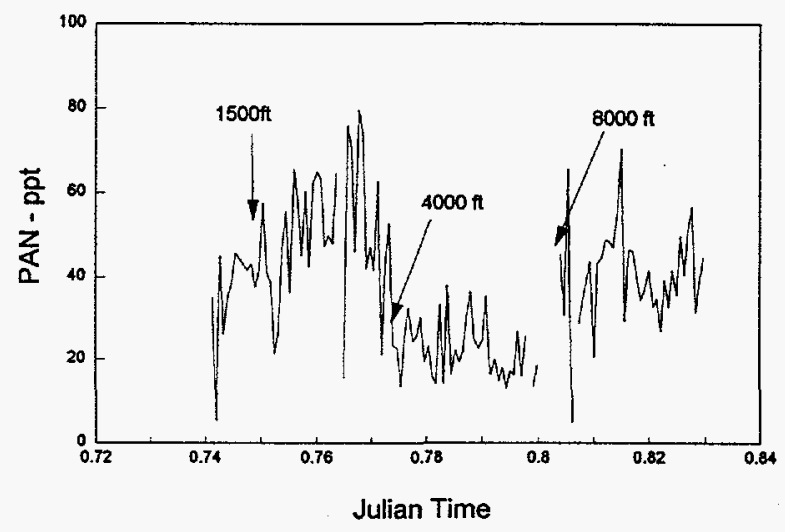

Figure 2. Peroxyacetyl nitrate (PAN) levels in ppt observed during aircraft flight no. 3 near Pasco, WA on August 13, 1997. 


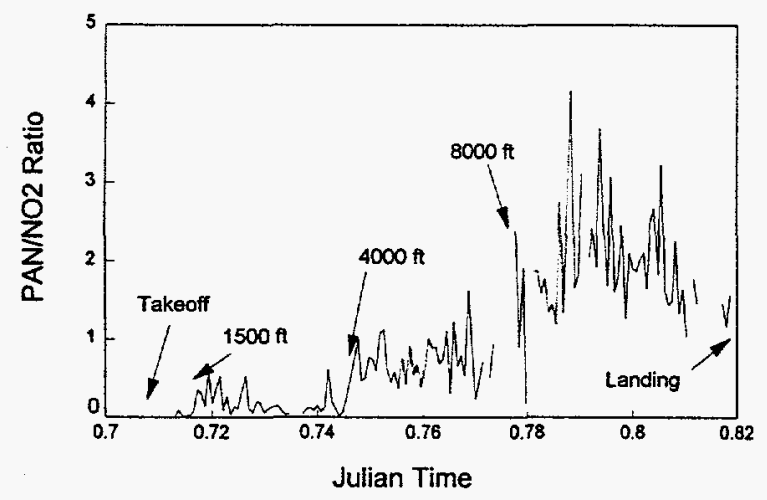

Figure 3. $\mathrm{PAN} / \mathrm{NO}_{2}$ ratio for the flight no. 3 taken on 8/13/97.

PAN levels were observed to be higher at the higher altitudes and at or below detection levels at the lower altitudes. This is likely due to the weather conditions at the time with approx. $40 \mathrm{C}$ ground temperatures. The levels aloft indicated that at least for this flight the upper air mass may have been marine sourced or representative of clean continental air with little impact from any sources.

These results, we believe, are the fastest analyses of PAN that has been accomplished to date. The improvement from 5 to 1 minute resolution, dramatically improves the potential for aircraft measurements of PANs and for low level, unambiguous, $\mathrm{NO}_{2}$ measurements. Further improvements in the reduction of the analysis time may be accomplished by redesigning the luminol detection chamber to remove the dead volume associated with the LMA-3 detection cell. Improvements may also be accomplished by using a cooled column to improve the separation while minimizing the retention time.

It should be noted that the luminol system is inherently more sensitive than the NO chemiluminescent reaction with ozone. This is due to the fact that the luminol emission is in the visible, while the $\mathrm{NO}_{2}{ }^{*}$ emission is in the far visible, near infrared. By coupling chromatography to the luminol detector a number of interferences can be used to advantage, i.e. they can be measured as well as the species of interest. This system does not require high vacuum or any toxic reagents and lends itself well to aircraft operations for these species by allowing lighter and safer equipment operation. Detection sensitivities in the low tens of ppt are readily accomplished using this approach. By using chromate converters or converting NO to peroxynitric acid it is anticipated that this type of instrumentation could also be used for $\mathrm{NO}$ as well as $\mathrm{NO}_{2}$ and PANs. Thermal conversion of organonitrates, nitro-aromatics, etc. to $\mathrm{NO}$ or $\mathrm{NO}_{2}$ could also be performed using this approach which will be useful in unraveling the various contributions of these species to tropospheric nitrogen oxides.

\section{ACKNOWLEDGMENT}

The authors wish to thank the aircraft operations group, particularly John Hubbe, Victor Morris, and Robert Hannigan of the Pacific Northwest National Laboratory for their assistance in making these test measurements. We also wish to acknowledge the continuing support of the United States Department of Energy, Office of Energy Research, Office of Biological and Environmental Research's Atmospheric Chemistry Program for the support of this research. Thanks also to Drs. Paul Doskey and Yoshiko Fukui of Argonne National Laboratory for their assistance and helpful discussions.

\section{REFERENCES}

Gaffney, J.S., R. Fajer, and G.I. Senum, 1984: An Improved Procedure for High Purity Gaseous Peroxyacetyl Nitrate Production: Use of Heavy Lipid Solvents. Atmos. Environ. 18 215-218.

Gaffney, J.S., N.A. Marley and E.W. Prestbo, 1989: Peroxyacyl Nitrates (PANS): Their Physical and Chemical Properties. the Handbook of Environmental Chemistry, Volume 4/Part B. (Air Pollution) edited by 0 . Hutzinger, 1-38, SpringerVerlag, Berlin, Germany.

Gaffney, J.S., N.A. Marley, and E.W. Prestbo, 1993: Measurements of Peroxyacetyl Nitrate (PAN) at a Remote Site in the Southwestern United States: Tropospheric Implications. Environ. Sci. Technol. 27 1905-1910.

Gaffney, J.S., R.M. Bornick, Y.-H. Chen, and N.A. Marley, in press: Capillary Gas Chromatographic Analysis of Nitrogen Dioxide and PANs with Luminol Chemiluminescent Detection. Atmospheric Environment.

Williams, J., J.M. Roberts, F.C. Fehsenfeld, S.B. Bertman, M.P. Buhr, P.D. Goldan, G. Hubler, W.C. Kuster, T.B. Ryerson, M. Trainer, and V. Young, 1997: Regional ozone from biogenic hydrocarbons deduced from airborne measurements of PAN, PPN, and MPAN. Geophys. Res. Lett. 24 1099-1102. 